УДК 616.3-053.1-053.31-083

DOI 10.11603/2411-1597.2019.2.10207

\title{
ОСОБЛИВОСТІ ДОГЛЯДУ ЗА НОВОНАРОДЖЕНИМИ 3 УРОДЖЕНИМИ ВАДАМИ ТРАВНОГО ТРАКТУ
}

\author{
Л. А. Воронова \\ ДВНЗ «Тернопільський національний медичний університет \\ імені І. Я. Горбачевського МОЗ Украӥни»
}

У статті розкрито особливості догляду за новонародженими з уродженими вадами травного тракту в хірургічних стаціонарах.

\section{FEATURES OF CARE FOR NEWBORNS WITH CONGENITAL DEFECTS OF GASTROINTESTINAL TRACT}

\author{
L. A. Voronova
}

\section{Horbachevsky Ternopil National Medical University}

The article deals with the features of care for newborns with congenital defects in the department of surgery.

Вступ. Вади розвитку шлунково-кишкового тракту виникають внаслідок порушення його формування в період ембріогенезу, вони $є$ найпоширенішими та вимагають діагностики в перші години після народження. Несвоєчасна діагностика призводить до ускладнень та погіршення перспективи на успіх лікування. Певний відсоток дітей з вадами розвитку шлунково-кишкового тракту мають супутні вади розвитку інших органів, що вимагає їх діагностики та вибору тактики послідовного лікування та догляду.

Основна частина. У перші години після операції необхідно встановити ретельне спостереження за новонародженим. Варто звернути увагу на профілактику блювання і ускладнень, пов'язаних із нею (аспірація!). Велике значення в післяопераційний період має знеболювання, яке особливо необхідне після об'ємних операційних втручань. Останнім часом із метою знеболювання у післяопераційний період у новонароджених впроваджують епідуральну анестезію [1, 3].

Положення дитини в ліжку залежить від характеру операції. Положення за Федоровим сприяє розслабленню черевної стінки, полегшує дихальний екскурс, запобігає розвитку пневмонії. Положення на здоровій стороні після втручання на легені зменшує ймовірність виникнення ателектазу. Після тяжких

(С Л. А. Воронова, 2019 операційних втручань на органах грудної та черевної порожнин необхідно забезпечити достатнє надходження кисню; останній подається у зволоженому вигляді через інкубаційну трубку; новонароджених розміщують в кювез. Частим і грізним ускладненням у післяопераційний період у дітей $є$ гіпертермія. 3 метою своєчасного її виявлення необхідно вимірювати температуру кожні 2 години. В післяопераційний період необхідний ретельний контроль за пульсом, частотою дихання, артеріальним тиском, вмістом гемоглобіну в крові. При затримці сечовиділення вводять катетер у сечовий міхур. Годування після операції призначають індивідуально $[2,6]$. При операційних втручаннях на травному тракті в більшості випадків дітей в день операції не годують. Після операцій на стравоході, через перитоніт, кишкову непрохідність протягом тривалого часу проводять парентеральне харчування, внутрішньовенно краплинно вводять глюкозу, плазму, ізотонічний розчин хлориду натрію, розчин Рінгера тощо. Після операцій у дітей необхідно звертати особливу увагу на профілактику пневмонії (оксигенотерапія, призначення антибіотиків, гірчичників, серцевих препаратів іт. д.). Після операційних втручань на органах черевної порожнини, особливо у маленьких дітей, нерідко розвивається парез кишечника. У такому разі при- 
значають газовідвідну трубку (на 30-40 хв), при відсутності ефекту ставлять гіпертонічну клізму $[4,8]$.

У післяопераційний період варто також звертати увагу на стан операційної рани: у перші години можливе просякання пов'язки кров'ю, в подальшому може початися нагноєння рани, ознакою чого $є$ інфільтрація і гіперемія $[2,9]$.

Незважаючи на значний прогрес у медицині, нові технології, що використовують в хірургії, залишається велика кількість хворих із сформованими кишковими стомами.

Відносне й абсолютне збільшення числа пацієнтів із сформованими кишковими стомами на сьогодні пов'язане зі зростанням кількості об'ємних процесів черевної порожнини та травматичними ушкодженнями кишечника. Поряд із цим зберігається значна кількість запущених форм захворювання з ускладненнями, що вимагає від хірургів виведення постійних або тимчасових стом. До цієї категорії належать пацієнти, яким неможливо виконати одномоментну відновлювальну операцію. Враховуючи необхідність збереження високої якості життя для пацієнта зі стомою актуальним $\epsilon$ правильно сформувати стому з подальшим повноцінним доглядом за нею як на рівні хірургічних стаціонарів, так і амбулаторно - на рівні медсестер $[3,8]$. Догляд здійснюють за таким алгоритмом:

\section{1. Догляд у ранній післяопераційний період:}

а) оцінка адекватності кровопостачання стоми;

б) захист стоми. Хоча надходження калу зазвичай мінімальне в ранній післяопераційний період, стому закривають калоприймачем для запобігання висиханню слизової, особливо якщо дитина перебуває під рефлектором. Марлеву пов'язку з вазеліном використовують в ранній післяопераційний період, якщо розміщення калоприймача відкладається через проблеми з герметичністю шкіри;

в) слизову норицю вкривають пов'язкою з гігроскопічного матеріалу для запобігання висиханню. Фіксуючи ії на новонародженому, використовують тонкий пластир. У новонароджених $є$ підвищений ризик ушкодження шкіри, особливо у недоношених із недостатньо розвиненим епідермісом. Уникають накладати марлю, просякнену вазеліном, на поверхню стоми, оскільки це погіршує герметизацію [6].

\section{2. Подальший догляд:}

а) регулярно оглядають стому;

б) захищають шкіру в ділянці стоми від впливу виділень з неї, для цього на стому накладають калоприймач. Виділення зі стоми тонкої кишки містить протеолітичні ферменти, які можуть швидко викликати ураження шкіри. При нормальному функціонуванні калоприймач повинен залишатися на місці як мінімум 24-72 год, його необхідно міняти при найменших ознаках підтікання вмісту. Однак часті замінювання калоприймача можуть призвести до злущування епітелію, особливо у недоношених.

У ситуаціях із частим підтіканням і заміною калоприймача може знадобитися допомога фахівця для профілактики ушкодження шкіри і бажаного часу його носіння. Якщо калоприймач не можна залишати, його знімають, а на шкіру навколо стоми накладають захисну пасту, яка дозволить шкірі загоюватися. Захисну мазь можна прикрити марлею, просякненою вазеліном, яку, в свою чергу, можна прикрити шаром чистої марлі.

У разі тяжкого ушкодження шкіри деякі неонатальні центри на короткий термін призупиняють ентеральне харчування, щоб обмежити утворення калу і дати можливість шкірі загоїтися.

в) захист стоми від травматизації. Заходи включають точне вимірювання розміру стоми, оскільки він змінюється. Якщо при рухах новонародженого внутрішні краї кільця калоприймача труться об стому, для її захисту потрібно використовувати відповідно до розміру стоми бар'єрне кільце калоприймача $[2,6]$.

Висновки. Надзвичайно велика роль в одужанні новонароджених у післяопераційний період належить хірургічній медичній сестрі. Правильне і своєчасне виконання лікарських призначень і чуйне ставлення до малечі створюють умови для їх швидкого одужання.

Диференційований підхід та ретельний післяопераційний догляд за стомою з використанням сучасних калоприймачів при уроджених вадах розвитку кишечника та некротизуючий ентероколіт новонароджених дозволяє знизити кількість післяопераційних ускладнень.

\section{СПИСОК ЛІТЕРАТУРИ}

1. Воробьев Г. И. Основы хирургии кишечных стом / Г. И. Воробьев, П. В. Царьков. - М. : ЗАО «Издательство «Стольный град», 2002. - 160 с.

2. Клиническая оперативная колопроктология : руководство для врачей / под ред. В. Д. Федорова, Г. И. Воробьева, В. Л. Ривкина. - М. : ГНЦ проктологии, 1994. - 432 с. 
3. Risk factors for recurrence after repair of enterocutaneous fistula / M. Brenner, L. Clayton, A. Tillou [et al.] // Arch. Surg. - 2009. - Vol. 144 (6). - H. 500-505.

4. Enteral fistula as a postoperative complication - a case report / Z. Pelák, P. Skála // Rozhl. Chir. - 2009. - Vol. 88 (6). 334-6.

5. Doughty D. B. History of ostomy surgery / D. B. Doughty // J. Wound Ostomy Continence Nurs. - 2008. - Vol. 35 (1). P. 34-8.

6. Hocevar B. Intestinal diversion (colostomy or ileostomy) in patients with severe bowel dysfunction following spinal cord injury / B. Hocevar, M. Gray // J. Wound Ostomy Continence Nurs. -2008. - Vol. 35 (2). - P. 159-166.
7. Bradshaw E. Managing a colostomy or ileostomy in community nursing practice / E. Bradshaw, B. Collins // Br. J. Community Nurs. - 2008. - Vol. 13 (11). - P. 514-518.

8. Black P. Stoma care nursing management: cost implications in community care / P. Black // Br. J. Community Nurs. - 2009. - Vol. 14 (8). - P. 350, 352-355.

9. Nybaek H., Karlsmark T., Laursen T.N. [et al.] // British Journal of Nursing. - 2006. - Vol. 15, No. 16. - P. 854-862.

Отримано 26.02.19 